\title{
Probing the equatorial groove of the hookworm protein and vaccine candidate antigen, $\mathrm{Na}$-ASP-2
}

Lyndel Mason ${ }^{1, \dagger}$, Leon Tribolet ${ }^{2, \dagger}$, Anne Simon ${ }^{3}$, Natascha von Gnielinski ${ }^{1}$, Lisa Nienaber ${ }^{1}$, Paul Taylor $^{4}$, Charlene Willis ${ }^{1,5}$, Malcolm K Jones ${ }^{5,6}$, Paul W Sternberg ${ }^{7}$, Robin B Gasser ${ }^{8}$, Alex Loukas ${ }^{2, *}$ \& Andreas Hofmann ${ }^{1,8, *}$

${ }^{1}$ Structural Chemistry Program, Eskitis Institute, Griffith University, Brisbane, Queensland, Australia

${ }^{2}$ Centre for Biodiscovery and Molecular Development of Therapeutics, Australian Institute of Tropical Health and Medicine, James Cook University, Cairns, Queensland, Australia ${ }^{3}$ Université Lyon 1, Villeurbanne cedex, and Laboratoire Chimie et Biologie des Membranes et des Nanoobjets, Université Bordeaux, CBMN, UMR 5248, 33600 Pessac, France

${ }^{4}$ Institute for Structural Biology, School of Biological Sciences, The University of Edinburgh, Scotland, UK

${ }^{5}$ School of Veterinary Science, The University of Queensland, Gatton, Queensland, Australia ${ }^{6}$ Queensland Institute of Medical Research, Herston, Queensland, Australia ${ }^{7}$ Biology Division, California Institute of Technology, Pasadena, CA, USA

${ }^{8}$ Faculty of Veterinary Science, The University of Melbourne, Parkville, Victoria, Australia

${ }^{\dagger}$ equal contributions

*corresponding authors:

Andreas Hofmann, Griffith University, N75 Don Young Road, Nathan, Qld 4111, Australia; Telephone: +61-7-3735-4425; Email: a.hofmann@griffith.edu.au

Alex Loukas, James Cook University, P.O. Box 6811, Cairns, Qld 4870, Australia; Telephone: +617-4232-1608; Email; alex.loukas@jcu.edu.au

Word count: $\quad 8801$

Character count: 57479

Last modified: $\quad 20$ Jan 2015 


\begin{abstract}
Hookworm activation-associated secreted proteins can be structurally classified into at least three different groups. The hallmark feature of Group 1 activation-associated secreted proteins is a prominent equatorial groove, which is inferred to form a ligand binding site. Furthermore, a conserved tandem histidine motif is located in the centre of the groove and believed to provide or support a yet to be determined catalytic activity.

Here, we report three-dimensional crystal structures of $\mathrm{Na}$-ASP-2, an L3-secreted activationassociated secreted protein from the human hookworm Necator americanus, which demonstrate transition metal binding ability of the conserved tandem histidine motif. We further identified moderate phosphohydrolase activity of recombinant $\mathrm{Na}$-ASP-2, which relates to the tandem histidine motif. By panning a random 12-mer peptide phage library, we identified a peptide with high similarity to the human calcium-activated potassium channel SK3, and confirm binding of the synthetic peptide to recombinant $\mathrm{Na}$-ASP-2 by differential scanning fluorimetry. Potential binding modes of the peptide to $\mathrm{Na}$-ASP-2 were studied by molecular dynamics simulations which clearly identify a preferred topology of the $\mathrm{Na}$-ASP-2:SK3 peptide complex.
\end{abstract}

\title{
Keywords
}

Activation-associated secreted proteins, Host-parasite interactions, Pathogenesis-related proteins, Protein structure, SCP/TAPS proteins

\section{Database}

Coordinates and structure factors have been deposited with the PDB, accession numbers 4nui, 4nuk, 4nun and 4nuo.

\section{Introduction}

Soil transmitted helminths (STHs), including hookworms, cause neglected tropical diseases (NTDs) affecting $>1$ billion people worldwide (Bethony et al., 2006). Hookworms alone infect approximately 700 million people, mostly in impoverished communities in tropical and subtropical areas, causing a disease burden of 1.5-22.1 million disability-adjusted life years (DALYs) (Hotez et al., 2010). Necator americanus is the predominant hookworm globally, causing the disease necatoriasis, characterized clinically by anaemia, malnutrition in pregnant women and an impairment of cognitive and/or physical development (particularly in children) (Loukas et al., 2011). The control of hookworm disease rests on currently available anthelmintic drugs such as albendazole, mebendazole and/or pyrantel, which are used to reduce the burden of disease in a range of countries (Diemert et al., 2008). However, due to the imminent risk of drug resistance, particularly through mass treatment programs, and logistical difficulties of sustaining these programs, recent efforts are directed towards finding novel interventions (Cantacessi et al., 2010). Such efforts require an improved knowledge of hookworm disease on the molecular and immunological levels, and, more specifically, the pathogen-host interactions. In this context, previous studies have suggested a prominent role for activation-associated proteins (ASPs) which are amongst the ten most abundant groups of proteins in hookworms (Cantacessi et al., 2009) and the major constituents of the excretory/secretory (ES) proteins released by the blood-feeding adult stage hookworms (Mulvenna et al., 2009). ASPs belong to a large group of proteins called the 'sperm-coating protein (SCP)-like extracellular proteins', also known as SCP/Tpx-1/Ag5/PR-1/Sc7 (SCP/TAPS; Pfam accession no PF00188). Topologically, ASPs are comprised of an N-terminal PR (or CAP) domain, a hinge region and a variable C-terminal extension domain, such as the ion 
channel regulator domain in cysteine-rich secretory proteins (CRISPs), C-type lectin domain or the LCCL (Limulus clotting factor C, coch-5b2, and Lgl1) domain (Gibbs et al., 2008). Several SCP/TAPS proteins have been characterised structurally and confirm the existence of a common fold of the CAP domain (see Figure 1) which consists of an $\alpha-\beta-\alpha$ sandwich in which the threestranded anti-parallel $\beta$-sheet is flanked by three helices on one side, and a fourth helix on the other (Fernández et al., 1997). These three, stacked layers are held together at the interfaces by a hydrophobic core. Recently, a structural classification using structure-based amino acid sequence alignments of hookworm ASPs defined at least three different groups of these proteins (Osman et al., 2012). Group 1 and 3 ASPs possess five disulphide bonds in the N-terminal CAP domain, whereas proteins from Group 2 lack one particular dithioether bond in this domain. Na-ASP-2 from the human hookworm Necator americanus is a member of the Group 1 ASPs, and its crystal structure has previously been determined (Asojo et al., 2005). Based on the observation that $\mathrm{Na}$ ASP-2 induces neutrophil and monocyte migration (Bower et al., 2008), it has been proposed that this molecule may be an antagonistic ligand of complement receptor 3 (CR3) and affects the immune cascade by preventing the binding of chemotaxin (Asojo et al., 2005).

Regarding molecular function and possible enzymatic activities, $\mathrm{Na}$-ASP-2 has been an enigmatic protein. Proteolytic activity has been speculated for this protein based on enzymatic activity observed for cone snail protease Tex31, a member of the CRISP family of pathogenesis-related proteins (Milne et al., 2003). Proteolytic activity was not detected for Na-ASP-1 or ASP-2, and from the crystal structure of the protein it is obvious that the proposed residues for this activity are not in spatial vicinity. Our recent classification of ASPs highlighted two distinctive features of Group 1 ASPs (see Figure 1): (i) the presence of a tandem histidine motif, which (ii) localises to a central position within an equatorial groove that extends approximately around half the protein of Group 1 ASPs. In close spatial vicinity of the tandem histidine motif (His88 and His148) are two acidic residues (Glu99 and Glu125). Such pairings of acidic with histidine residues have previously been observed in enzymatic sites, which also includes phosphoesterases (Hofmann et al., 2000b).

In the present study, we tested three hypotheses concerning the equatorial groove of $\mathrm{Na}$-ASP-2. Firstly, we formulated the hypothesis that the tandem histidine motif in Group 1 ASPs may be able to serve as a general metal binding site (Osman et al., 2012). Recent crystal structures have revealed that Group 1 ASPs bind zinc ions in this site; these include natrin (Wang et al., 37872-37883), pseudecin (Suzuki et al., 2008) and GLIPR1 (Asojo et al., 2011). Secondly, we previously proposed that the shape and extent of the equatorial groove of Group 1 ASPs allows the binding of extended structures, such as peptides or glycans (Osman et al., 2012). Lastly, since the tandem histidine motif is reminiscent of that found in cyclic phosphodiesterases, we investigated the enzymatic phosphohydrolase activity of $\mathrm{Na}$-ASP-2.

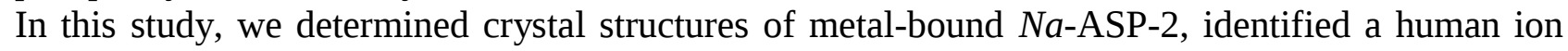
channel as a potential receptor of $\mathrm{Na}$-ASP-2 and suggest a binding mode based on molecular dynamics simulations. We also show that $\mathrm{Na}$-ASP-2 possesses phosphohydrolase activity, which relates to the tandem histidine motif.

\section{Materials and Methods}

\subsection{Mutagenesis}

Using the cDNA of wild-type Na-ASP-2 in pPICZ $\alpha$ A (Asojo et al., 2005) as template, site-directed mutagenesis based on the QuickChange/DpnI method (Zheng et al., 2004) was employed to generate the Na-ASP-2-H88A mutant. Complementary oligonucleotides carrying a single codon 
change (coding: 5'-GTA-TTC-AAG-GCC-TCG-CAA-CCT-AAC-CAA-AGG-AAA-GGA-TTGGG-3', anti-coding: 5'-G-GTT-AGG-TTG-CGA-GGC-CTT-GAA-TAC-ACA-TTG-TTT-CGC-G3') were used in a PCR reaction with PfuUltra II Fusion HS DNA Polymerase (Agilent, Mulgrave, Victoria, Australia). Chemically competent Escherichia coli XL1Blue cells generated in house were used for transformation. Single colonies were picked, propagated and cDNA was purified using the NucleoBond Xtra kit (MN; Scientifix Life, Brisbane, Queensland, Australia). The H88A mutation was confirmed by site-specific restriction enzyme digest with Stu1 and DNA sequencing using BigDye chemistry.

\subsection{Expression of recombinant protein}

The yeast expression plasmid of either wild-type or mutant Na-ASP-2 in pPICZ $\alpha$ A vector (Invitrogen; Life Technologies, Mulgrave, Victoria, Australia) (Goud et al., 2005) was transformed into Pichia pastoris, and colonies resistant to $500 \mathrm{mg} \mathrm{mL}^{-1}$ of zeocin were selected for protein expression in a $1 \mathrm{~L}$ biomass culture according to the manufacturer's instructions. Methanol was added to a final volume of $0.5 \%$ every 24 hours for four days. The medium was separated from the cells by centrifugation, subjected to ultrafiltration in a pressure cell (Amicon; Merck Millipore, Kilsyth, Victoria, Australia) to a volume of $\sim 50 \mathrm{~mL}$, and subjected to dialysis against $50 \mathrm{mM}$ NaAc ( $\mathrm{pH}$ 4.5). After dialysis, the solution was applied to an SP-Sepharose column equilibrated with the same buffer. Following a washing step with 3 column volumes, contents were eluted and fractionated with a gradient $0-1 \mathrm{M} \mathrm{NaCl}, 50 \mathrm{mM}$ NaAc (pH 4.5). Fractions containing Na-ASP-2 were pooled, dialysed against $20 \mathrm{mM}$ TRIS ( $\mathrm{pH}$ 8.0), and subjected to anion exchange chromatography using Q-Sepharose and a gradient of 0-1 M NaCl, $20 \mathrm{mM}$ TRIS (pH 8.0). Proteincontaining fractions were pooled, concentrated and dialysed against $100 \mathrm{mM} \mathrm{NaCl}, 20 \mathrm{mM} \mathrm{HEPES}$ (pH 8.0). All purification steps were monitored throughout with SDS-PAGE (see Figure S1).

\subsection{Phage display}

We used a phage display-12 peptide library kit with lambda bacteriophage M13KE (New England Biolabs; Genesearch, Arundel, Qld, Australia) to identify 12-mer peptides that bound to recombinant $\mathrm{Na}$-ASP-2. Phage were engineered to express a peptide fused to the pIII coat protein of the M13 bacteriophage, resulting in $2.7 \times 10^{9}$ possible combinations of peptides displayed on the surface of the virions. Phage were used to infect E. coli ER2738 F' lacZ M15. The vector carries the lacZ $\alpha$ gene, and the F-factor of ER2738 contains a mini transposon that confers tetracycline resistance. Selection was carried out on Luria Bertani agar plates containing Xgal and isopropyl $\beta$ D-1-thiogalactopyranoside, supplemented with tetracycline as described by the manufacturer. Positive, non-lytic plaques appeared blue on the plated agar. Three rounds of panning were carried out in triplicate at $4^{\circ} \mathrm{C}$ in 24 well plates coated with $\mathrm{Na}$-ASP-2 at concentrations of $50 \mu \mathrm{g} \mathrm{mL}$ (first $^{-1}$ pan), 25 and $10 \mu \mathrm{g} \mathrm{mL}^{-1}$ for the second and third pans, respectively. Phage libraries were plated at varying dilutions $\left(10^{-2}\right.$ to $\left.10^{-6}\right)$ to obtain approximately 100 plaques per plate. Twelve plaques were selected from each plate after the third round of panning, and single-stranded phage DNA was purified according to the manufacturer's instructions and submitted for automated dideoxy sequencing (Macrogen, Seoul, South Korea).

\subsection{Database searches}

Peptides were submitted to BLASTp (Altschul et al., 1997) searches against the human refseq genome at GenBank. Peptide features were calculated using the peptide property calculator (https://www.genscript.com/ssl-bin/site2/peptide_calculation.cgi) and PEPTIDES (Hofmann \& Wlodawer, 2002). 


\subsection{SK3 peptide}

The synthetic purified peptide SK3(244-255), ATHNHQHAGTTA, was obtained from the QIMR peptide synthesis service (Queensland Institute of Medical Research, Herston, Australia).

\subsection{Crystal structure determination}

Monoclinic and orthorhombic Na-ASP-2 crystals were obtained by the hanging drop vapour diffusion method from 30-40\% PEG2000 or PEG4000, 20 mM MOPS (pH 6.0-7.5), using a protein stock solution of $16 \mathrm{mg} \mathrm{mL}^{-1}$. In order to obtain ligand-bound $\mathrm{Na}$-ASP-2 crystals, co-crystallisation as well as soaking experiments were conducted (see Table 1).

For cryo-protection, crystals were immersed in a 1:1 mixture (v/v) of paratone $\mathrm{N}$ and mineral oil. Xray diffraction data were collected at the in-house diffractometer (Rigaku MicroMax007-HF; RAxis IV++ detector; Rigaku X-stream cryo equipment), and at beam lines MX1 and MX2 of the Australian Synchrotron under cryogenic conditions $(T=100 \mathrm{~K})$ and wavelengths allowing for observation of anomalous signals of metals. Datasets were indexed with XDS (Kabsch, 1993) and Mosflm (Leslie, 1992), and scaling, truncation and analysis was performed with programs from the CCP4 suite (Collaborative Computational Project Number 4, 1994). Crystal structures were solved by molecular replacement using the known structure of $N a$-ASP-2 (PDB: 1u53) as template. Isomorphous and anomalous difference electron densities were calculated to locate metal ions. Model building was performed with O (Jones et al., 1991) and Coot (Emsley \& Cowton, 2004), and interspersed with computational refinement of atomic positions, grouped and individual B-factors using PHENIX (Adams et al., 2010). For data collection and refinement statistics see Table 1. The geometry of the final models was scrutinised using MolProbity tools as implemented in PHENIX.

\subsection{Differential scanning fluorimetry}

The optimal ratio of protein and fluorescence dye was optimised by testing a $4 \times 5$ matrix of conditions varying Na-ASP-2 concentration from $2.5 \mu \mathrm{M}$ to $40 \mu \mathrm{M}$, and SYPRO Orange (Invitrogen; Life Technologies, Mulgrave, Victoria, Australia) concentration between $5 \times$ and 20×, using a sample volume of $20 \mu \mathrm{L}$ with a buffer composed of $100 \mathrm{mM} \mathrm{NaCl,} 20 \mathrm{mM}$ HEPES (pH 7.5). The best conditions were determined to contain $10 \mu \mathrm{M}$ protein and $5 \times$ SYPRO Orange.

At least three technical replicas were then tested for $N a$-ASP-2 mixes with various ligands using the optimised protein-dye ratio. Ligands were added at a final concentration of $10 \mu \mathrm{M}$ (metals) and 100 $\mu \mathrm{M}$ SK3 peptide, respectively, in $20 \mu \mathrm{L}$ sample aliquots. Experiments were conducted on a Roche LightCycler 480, and analysed using the software DMAN (Wang et al., 2012). $\Delta \mathrm{T}_{1 / 2}$ values were calculated with respect to the addition of water which was the solvent used for all ligand stock solutions.

\subsection{Enzyme activity assays}

Potential phosphatase enzymatic activity of $\mathrm{Na}$-ASP-2 was investigated using para-nitrophenyl phosphate (pNPP) in stopped flow experiments with UV/VIS monitoring; pNPP was used as a substrate at a final concentration of $50 \mu \mathrm{M}$, and the final concentration of Na-ASP-2 in the stopped flow assays was $5 \mu \mathrm{M}$. Both the substrate and enzyme solutions were prepared in a buffer containing $100 \mathrm{mM}$ NaAc, $50 \mathrm{mM}$ PIPES and $50 \mathrm{mM}$ TRIS at varying $\mathrm{pH}$. Metals or EDTA were added to both solutions at a concentration of $5 \mu \mathrm{M}$. For experiments in the presence of the SK3 peptide, the peptide was added to the enzyme solution such that the final concentration was $50 \mu \mathrm{M}$. Stopped flow experiments were carried out with a Bio-Logic SFM MOS-LED instrument, equipped with a $100 \mu \mathrm{L}$ flow cell, and absorbance readings at $400 \mathrm{~nm}$. All solutions were prepared freshly before the experiment. The amount of product, $p$-nitrophenol, was determined using a molar extinction coefficient of $18000 \mathrm{~L} \mathrm{~mol}^{-1} \mathrm{~cm}^{-1}$ (MacKintosh, 1993). One unit of protein phosphatase 
activity is defined as the amount of enzyme that hydrolyses $1 \mathrm{nmol}$ of pNPP in one minute in a total reaction volume of $1 \mathrm{~mL}$ under standard reaction conditions.

\subsection{Bioinformatics}

Database searches for homologous protein sequences in the GenBank database were conducted using the BLASTp algorithm (Altschul et al., 1997), as well as a local installation of the pGenThreader software (Lobley et al., 2009).

\subsection{Molecular dynamics (MD) simulations}

MD simulations were conducted using the program Gromacs (van der Spoel et al., 2005) installed on in-house servers (Intel XEON X3220 Quad Core; AMD Phenom X4 9850 Quad Core CPUs), following the tutorial by Kerrigan (Kerrigan, 2003). The Gromacs 43a1 force-field and the spc water model were used. A peptide comprising residues 244-255 of the human SK3 channel was generated in an extended conformation, and manually placed above the equatorial groove of $\mathrm{Na}$ ASP-2 with O (Jones et al., 1991), in two opposite directions. To ensure a charge-neutral cell, chloride counter ions were added by replacing solvent molecules at sites of high electrostatic potential. A position-restrained dynamics simulation of 20 ps was performed to equilibrate the solvated protein-ligand complex and to gradually heat the simulation cell to $300 \mathrm{~K}$. The production MD simulation was carried out for a simulation time of $50 \mathrm{~ns}$, with periodic boundary conditions being applied in all three dimensions, and employing the Particle Mesh Ewald (PME) method to treat the long-range electrostatic interactions. Trajectories were analysed using Gromacs tools.

\section{Results}

\subsection{Phage panning and identification of potential targets}

From five separate panning experiments of random 12-mer peptide phage display libraries, 16 peptides were identified after three successive rounds of panning (Table 2). One peptide (KLIGHNQQHAIL) was identified in two independent screens of the library, and two additional peptides (LHQPKDW/RHSRQH) had a single amino acid difference. All of the peptides except for one had a net positive charge, with 11 having pI values greater than 9 (see Table 2). Most of the identified peptides were enriched for glutamine and histidine residues. Three peptides possessed a HXXQH motif, and a fourth peptide contained the highly similar HXXXH motif. BLASTp searches of public databases with an emphasis on the human proteome identified many distinct proteins containing varying degrees of similarity to different regions within the peptides; however, no peptide had a perfect match across its entire sequence length (12 residues) to known proteins, implying that binding of $\mathrm{Na}$-ASP-2 to its native ligand is dependent on shorter peptides, possibly those containing an HXXQH motif. One such protein was the SK3 small conductance calciumactivated potassium channel, a transmembrane protein that contained a HNHQH motif within its extracellular domain.

\subsection{Differential scanning fluorimetry}

Recombinant Na-ASP-2 was subjected to thermal protein denaturation in the presence of different metal ions, and combinations of metal ions and the peptide derived from the extra-cellular domain of human SK3 channel.

From the panel of metal ions tested, only zinc and copper showed a shift of $\mathrm{T}_{1 / 2}$ of more than $1 \mathrm{~K}$ (see Table 3). A strong positive shift $\left(\Delta \mathrm{T}_{1 / 2} \geq 1 \mathrm{~K}\right)$ of the melting temperature of $N a$-ASP-2 was observed in the presence of the SK3 peptide, suggesting binding of the peptide to the protein. Notably, this shift was independent of the presence of metal ions. 


\subsection{Crystal structures of metal-bound Na-ASP-2}

In order to investigate metal binding at the tandem histidine motif in Na-ASP-2, co-crystallisation and soaking experiments were conducted using five different transition metals. From this panel, complex formation of four metal ions $\left(\mathrm{Ni}^{2+}, \mathrm{Co}^{2+}, \mathrm{Zn}^{2+}\right.$ and $\left.\mathrm{Cu}^{2+}\right)$ with the side chains of His88 and His148 were observed, as indicated by isomorphous and anomalous difference density maps (see Figure 2 and Table 3). For manganese, no metal-bound crystal structures of $\mathrm{Na}$-ASP-2 could be obtained.

\subsection{Molecular modelling of the Na-ASP-2:SK3 complex}

Topologically, the SK3 small conductance calcium-activated potassium channel is composed of an N-terminal extracellular domain, the transmembrane domain, an intracellular calmodulin-binding domain, and by a C-terminal moiety. Secondary structure prediction shows no structured elements in the extracellular domain, and no homologous proteins could be identified by database searches using pGenThreader and BLASTp.

To investigate potential binding modes of $\mathrm{Na}$-ASP-2 to the SK3 extracellular domain by molecular dynamics (MD) simulations, the peptide comprising residues 244-255 of the human SK3 channel was chosen as a target. A linear peptide in extended conformation was generated in silico, and manually docked above the equatorial groove of $\mathrm{Na}$-ASP-2 in two opposite directions. MD simulations were conducted in the presence and absence of a metal ion $\left(\mathrm{Zn}^{2+}\right)$, initially coordinated by histidine residues 88 and 148 .

The simulations were conducted for $50 \mathrm{~ns}$, and comparison of the two complex topologies with opposite directions of the SK3 peptide clearly indicate a preferred direction (Figure 3, Table 4). The preferred direction is stabilised by approximately $-3100 \mathrm{~kJ} \mathrm{~mol}^{-1}$, and this is independent of the presence or absence of a zinc ion coordinated by the tandem histidine motif. The preference for one of the two directions is also clearly obvious when monitoring the distance between the centres of gravity between the SK3 peptide and Na-ASP-2. For the preferred topology (direction 1), this distance decreases over the time course of the simulation, whereas it increases in the case of the non-preferred topology.

An interesting phenomenon is observed when comparing the MD simulations for direction 1 in the absence and presence of a zinc ion coordinated by the tandem histidine motif. In the absence of the metal ion, the SK3 peptide adopts an almost linear conformation in the protein-bound state, and Arg144 of Na-ASP-2 swings over the peptide in a clamp-like fashion (see Figure 3). This conformational change of the protein is not seen in the presence of a zinc ion. Although the peptide is able to form a significantly stabilised protein-bound state, its conformation is not as linear as in the absence of the metal. The distance of the peptide from the protein is also $\sim 2 \AA$ larger in the zincbound case.

\subsection{Enzymatic activity}

In order to evaluate the potential enzymatic activity of $\mathrm{Na}$-ASP-2, we investigated whether the wild-type and a His88-defective mutant protein possessed phosphatase activity in the presence and absence of divalent metal ions, using $p$-nitrophenyl phosphate ( $p N P P$ ) as a substrate. Enzyme activities were expressed as specific phosphatase activity (units $\mathrm{mg}^{-1}$ ), whereby one unit of protein phosphatase activity is defined as the amount of enzyme that hydrolyses $1 \mu \mathrm{mol}$ of $p$ NPP in one min at $37^{\circ} \mathrm{C}$ in a total reaction volume of $1 \mathrm{ml}$ under standard reaction conditions.

Comparison between reactions conducted in the absence (control) and the presence of Na-ASP-2, shows that the wild-type protein possesses moderate phosphatase activity (see Table 5). In comparison with commercially available calf intestine phosphatase with a specific activity of $>1600$ 
units per mg, the phosphatase activity of $\mathrm{Na}$-ASP-2 is approximately 60 times less. This enzymatic activity of Na-ASP-2 is independent of transition metal ions as the highest activity is observed in the presence of EDTA. Enzyme activities determined for the mutant defective of His88 yielded values at the level of the control reactions, thus indicating that the side chain of His88 is crucial for this enzymatic activity.

Notably, in the presence of the divalent earth alkali metal ion calcium that cannot coordinate to nitrogen, both wild-type and mutant protein show significant phosphatase activity. This activity is clearly located on the protein, since the calcium control reactions do not show hydrolysis of the substrate. That wild-type and the H88A mutant possess this activity indicates that Na-ASP-2 possesses another metal binding site, where calcium can act as a catalytic centre for phosphatase activity. This metal binding site appears to be specific for calcium, since magnesium did not elicit any phosphatase activity in the assays conducted.

In the presence of the SK3 peptide, the observed enzymatic activity of Na-ASP-2 is abolished entirely (in the presence of nickel ions), or reduced to levels of 20\%-40\% (all other tested metal ions, except magnesium). In the presence of magnesium ions and SK3 peptide, a slight increase of the phosphohydrolase activity is observed.

\section{Discussion}

\subsection{Potential host receptors of Na-ASP-2}

In contrast to the abundance of ASPs excreted or secreted from the blood-feeding stage of hookworms, only two host proteins have been identified as targets for these proteins. The only confirmed, direct interaction between an ASP and host receptor reported to date has been for the neutrophil inhibitory factor (NIF) and integrin $\beta 2$ (also named complement receptor CR3 or CD18) (Muchowski et al., 1994). In the absence of experimental structural information for the NIF:integrin complex, a homology model had been proposed that used the crystal structure of Na-ASP-2 as a template for NIF (Asojo et al., 2005). Intriguingly, this model proposed that the residue involved in the interaction of integrin with NIF was Glu125 of Na-ASP-2, one of the residues that is conserved among members of Group 1 and part of a tetrad of residues likely involved with the phosphohydrolase activity. However, since $N a$-ASP-2 is a Group 1 and NIF a Group 3 ASP, there is a serious caveat regarding the level of similarity between template and target in this homology model. In addition, there is presently no experimental proof for any interaction between $\mathrm{Na}$-ASP-2 and host integrins.

Here, we sought to identify Na-ASP-2 interacting peptide sequences by phage display experiments, and obtained an amino acid sequence motif with homology to the extracellular domain of SK3, an ion channel in the human intestine as well as the vascular endothelium where it plays important roles in regulating vascular tone (Lin et al., 2012). SK small conductance calcium-activated potassium channels are comprised of heteromeric channels formed by SK1 ( $\left.\mathrm{K}_{\mathrm{Ca}} 2.1\right)$, SK2 (Ka 2.2 ) and SK3 (K $\left.\mathrm{Ka}_{\mathrm{Ca}} 2.3\right)$ (Monaghan et al., 2004).

Intriguingly, $\mathrm{Na}$-ASP-2 is able to induce neutrophil recruitment into areas of acute inflammation, and it has been speculated that this may act as a promoting factor of inflammation during tissue migration to increase tissue permeability (Bower et al., 2008). SK channels mediate the production of reactive oxygen species that may be used for oxidative destruction of pathogens (Fay et al., 2006). Thus, it is tempting to speculate that Na-ASP-2 excreted/secreted by the migrating larvae could interfere with this process by modulating the SK3 ion channel.

Although SK channels have been well characterised in neurons (Blatz \& Magleby, 1986; Bond et al., 2004; Köhler et al., 1996) and endocrine cells (Nagayama et al., 2000; Tamarina et al., 2003; Uceda et al., 1992), they have been investigated only recently in non-excitable cells such as immune 
cells (Fay et al., 2006; Jäger et al., 2000; Quesada et al., 2001). Biologically, SK channels can be blocked by the cyclic peptide apamin found in bee venom toxin (Habermann, 1984). The compound $N$-cyclohexyl- $N$-[2-(3,5-dimethyl-pyrazol-1-yl)-6-methyl-4-pyrimidinamine (CyPPA) has been reported as a selective activator of SK2 and SK3 channels (Hougaard et al., 2007), and several selective small molecule channel blockers have been developed (Chen et al., 2000; Faber \& Sah, 2002). Neuron hyper-excitability is an essential component of many disorders of the central nervous system (Curatolo et al., 2001), and also plays a role in the molecular basis of addiction (Koob \& Le Moal, 2001) and autoimmune disorders (Hart et al., 2002). In particular, it produces enhanced pain transmission in the spinal dorsal horn after spinal cord injury (Gwak \& Hulsebosch, 2011). Recently, the SK3 ion channel has gained attention as a new therapeutic target for disorders involving neuron hyper-excitability (Schlichter et al., 2010). Results from the present study suggest direct interactions between $\mathrm{Na}$-ASP-2 and extracellular SK3 peptides, thus raising the hope that this hookworm protein may hold promise as a new SK3 channel modulator with therapeutic potential.

\subsection{Metal binding}

Previous indications of $\mathrm{Na}$-ASP-2 metal interactions have focussed on zinc as the binding partner for this protein, presumably, because this metal has been identified previously in proteins of the PR1 family, to which the hookworm ASPs belong. Zinc-bound structures have been determined for natrin (PDB: 3mz8), pseudecin (PDB: 2epf) and sGLIPR1 (PDB: 3q2r). Other metal-bound PR-1 structures include triflin (cadmium, PDB: 1wvr) and Ac-ASP-7 (calcium, PDB: 3s6u; manganese, PDB: 3s6v). Natrin, a CRISP family member of the cobra snake, modulates the inflammatory response by inducing expression of vascular endothelial cell adhesion molecules in a zinc- and heparan sulphate-dependent manner (Wang et al., 2010). Intriguingly, natrin also possesses the prominent tandem histidine motif (His60, His115), flanked by acidic amino acid side chains (Glu75-His60, Glu96-His115), and can coordinate zinc ions at this site (PDB: 3mz8). Our results show that hookworm $\mathrm{Na}$-ASP-2 can coordinate a variety of transition metal ions at this prominent motif. Whereas differential scanning calorimetry yielded significant binding for copper and zinc ions only, crystal structures of metal-bound $\mathrm{Na}$-ASP-2 show that nickel and cobalt ions can also be coordinated by the protein. In contrast, manganese ions do not seem to be a suitable ligand, since no binding was observed using either method.

Previously, a similar observation has been made with Ac-ASP-7, a Group 2 ASP from the dog hookworm Ancylostoma caninum. The crystal structure of this protein revealed an unanticipated binding site for calcium and manganese, whereas isothermal titration calorimetry did not indicate significant binding in solution (Osman et al., 2012). Thus, it is possible that the affinity of ASPs for these metals in solution increases in the presence of a dedicated binding partner.

Although extrapolation of ligand binding data to other proteins in the absence of experimental evidence needs to be treated with caution, it would be tempting to speculate that the ability to coordinate transition metal ions at the tandem histidine motif is a general property of all Group 1 ASPs.

\subsection{Enzymatic activity}

In an attempt to better understand the molecular mechanisms of $\mathrm{Na}$-ASP-2, a previous hypothesis that this protein possesses enzymatic activity was tested. In particular, protease activity has been suggested as a shared feature of PR-1 proteins based on structure-function inference from the cone snail protease Tex31 (Milne et al., 2003), but could not be demonstrated to date. We were intrigued by the structural similarity of the tandem histidine motif of Group 1 ASPs with enzymatic sites found in phosphodiesterases such as the Arabidopsis CPDase (Hofmann et al., 2000b), and thus investigated the possibility that $\mathrm{Na}$-ASP-2 might possess phosphohydrolase activity. 
Our findings from stopped flow assays using $p$-nitrophenyl phosphate as a substrate show that the hookworm Group 1 ASP indeed possesses phosphatase activity, albeit moderate, when compared with calf intestinal phosphatase. Importantly, since this activity is detected for wild-type $\mathrm{Na}$-ASP-2 but not the H88A mutant, we could locate this phosphohydrolase activity to the tandem histidine motif. The enzymatic activity at this motif is metal-independent and likely to involve the tetrad of Glu99, His88, His148 and Glu125. In the presence of divalent transition metal ions, this activity is significantly reduced, most likely, because the coordinated metal ion either directly interferes with the enzymatic reaction or simply obstructs access to the catalytic side chains.

Surprisingly, phosphohydrolase activity is also observed in the presence of calcium (but not magnesium) in both the wild-type and the H88A mutant proteins. This finding indicates the presence of a calcium-specific binding site on the protein where all structural requirements for the processing of phosphoesters are met. There is precedence for the occurrence of such "unintentional" enzymatic activity. In plant annexins, for example, moderate phosphodiesterase activity has been observed (Hofmann et al., 2000a; Lim et al., 1998; McClung et al., 1994) and located to the calcium binding loops (Lim et al., 1998). Although it is presently unknown where the calcium-binding site on Na-ASP-2 might be located, such "incidental" binding of divalent earth alkali metals has been observed previously for a Group 2 ASP, namely Ac-ASP-7 (Osman et al., 2012).

Future studies will need to address potential physiological roles of this enzymatic activity. Clues may be obtained from previous observations for GAPR-1, a human protein of the PR-1 family, which binds inositol-hexakisphosphate (van Galen et al., 2012). Intriguingly, Na-ASP-2 surface electrostatics show uniformly basic regions above and below the equatorial binding groove (see Figure 1), which may provide an interaction interface with negatively charged phospholipid membrane surfaces and position inositol phosphate for subsequent enzymatic hydrolysis.

\subsection{Insights into the potential Na-ASP-2:SK3 binding mode}

Results from the phosphohydrolase activity assays in the presence of the SK3-derived peptide show a reduction of activity under all tested conditions except for the presence of magnesium ions (see Table 5). This can be explained if one assumes a binding mode whereby the peptide binding site overlaps with the active site which we have located at the tandem histidine motif. These experimental data are thus in excellent agreement with the binding mode we predict based on molecular dynamics simulations (see Figure 3). Intriguingly, the enzymatic activity is completely abolished in the presence of nickel ions. Reminiscent of the mechanisms used in the wellestablished immobilised metal affinity chromatography (Hemdan et al., 1989), it is tempting to assume that this metal with its high affinity for nitrogen engages in a complex that involves His88 and His148 from $\mathrm{Na}$-ASP-2 as well as any of the three histidine residues (His246, His248, His250) of the SK3 peptide. This transition metal complex could strengthen the Na-ASP-2:SK3 interactions and thus hold the peptide bound firmly in place.

\subsection{Implications of ASP-2/SK3 interactions at the host-parasite interface}

Ion channels are of interest as novel targets of a diverse range of therapeutics because they modulate calcium signaling cascades and membrane potential in both excitable and non-excitable cells (Dilly et al., 2011; Wulff et al., 2007).While ion channels are best known for their roles in neuronal and cardiac action potentials, their importance in immune cells is less well characterised, but a role in mediating reactive oxygen species (ROS) production and apoptosis in granulocytes has been described (Fay et al., 2006). An activator of SK channels (1-EBIO) causes production of ROS by neutrophils and granulocyte-differentiated PLB-985 neutrophil-like cells, and this response can be blocked by the bee venom SK3-binding protein, apamin (Fay et al., 2006). It is tempting to suggest that $\mathrm{Na}$-ASP-2 has a similar function and blocks the production of reactive oxygen species that are toxic to invading hookworm larvae as they migrate through host tissues on their sohourn 
towards the gastrointestinal tract. In microglial cells, SK3 channels can modulate LPS-induced inflammatory responses (Dolga et al., 2012), and given the potent anti-inflammatory properties of hookworm ES products (Ferreira et al., 2013), it is reasonable to assume that $\mathrm{Na}$-ASP-2 might also suppress production of pro-inflammatory cytokines. Taken together, these findings suggest a potential role for Na-ASP-2 in direct interactions with SK3 channels on T cells or granulocytes, blocking their activation and thereby interrupting inflammatory cascades in affected cells to promote parasite survival in the hostile host microenvironment.

\section{Conclusion}

At least one ASP has previously been implicated in immunomodulation of the host by bloodfeeding hookworms (Cantacessi et al., 2009). The high abundance of these excreted/secreted proteins during the intra-mammalian stages of the hookworm is contrasted by a paucity of known host receptors. The only known interaction underpinned by experimental evidence is that of the Group 3 ASP, neutrophil inhibitory factor (NIF) with a human integrin. Several other members of the PR-1 family of proteins are known toxins, i.e. effectors of host ion channels (Gibbs et al., 2008). Group 2 ASPs, including $\mathrm{Na}$-ASP-2, possess a conserved equatorial binding groove with a prominent tandem histidine motif (Osman et al., 2012). Here, we provide a molecular and functional characterisation of this structural feature, and also identified the human SK3 channel as a likely target of $\mathrm{Na}$-ASP-2. Considering the emerging importance of the SK3 channel as a therapeutic target for disorders involving neuron hyper-excitability, our current findings highlight the potential of hookworm ASPs as therapeutic tools for a variety of disorders, including addiction, pain, and autoimmune diseases.

\section{Acknowledgements}

This study was supported by the Australian Research Council (RBG, AH, AL and PWS). We also gratefully acknowledge funding of our laboratories by the National Health and Medical Research Council (AH, MKJ, AL, RBG). LT is the recipient of an Australian Postgraduate Award. AL is the recipient of a principal research fellowship from NHMRC. Parts of this research were undertaken on the MX1 beamline at the Australian Synchrotron, Victoria, Australia.

Supplementary Data accompanies this paper. Figure S1: Quality control of purified recombinant proteins. 


\section{References}

Adams PD, Afonine PV, Bunkóczi G, Chen VB, Davis, IW, Echols N, et al. PHENIX: a comprehensive Python-based system for macromolecular structure solution. Acta Crystallogr D 2010;66:213-21.

Altschul SF, Madden TL, Schäffer AA, Zhang J, Zhang Z, Miller W, et al. Gapped BLAST and PSI-BLAST: a new generation of protein database search programs. Nucleic Acids Res 1997;25:3389-402.

Asojo OA, Goud G, Dhar K, Loukas A, Zhan B, Deumic V, et al. X-ray structure of Na-ASP-2, a pathogenesis-related-1 protein from the nematode parasite, Necator americanus, and a vaccine antigen for human hookworm infection. J Mol Biol 2005;346:801-14.

Asojo OA, Koski RA, Bonafé N. Structural studies of human glioma pathogenesis-related protein 1. Acta Crystallogr D 2011;67:847-55.

Bethony J, Brooker S, Albonico M, Geiger SM, Loukas A, Diemert D, et al. Soil-transmitted helminth infections: ascariasis, trichuriasis, and hookworm. Lancet 2006;367:1521-32.

Blatz AL, Magleby KL. Single apamin-blocked Ca-activated K+ channels of small conductance in cultured rat skeletal muscle. Nature 1986;323:718-20.

Bond CT, Herson PS, Strassmaier T, Hammond R, Stackman R, Maylie J, et al. Small conductance $\mathrm{Ca} 2+$-activated $\mathrm{K}+$ channel knock-out mice reveal the identity of calcium-dependent afterhyperpolarization currents. J Neurosci 2004;24:5301-6.

Bower MA, Constant SL, Mendez S. Necator americanus: the Na-ASP-2 protein secreted by the infective larvae induces neutrophil recruitment in vivo and in vitro. Exp Parasitol 2008;118:569-75. Brünger A. Free R value: a novel statistical quantity for assessing the accuracy of crystal structures. Nature 1992;355:472-5.

Cantacessi C, Campbell BE, Visser A, Geldhof P, Nolan MJ, Nisbet AJ, et al. A portrait of the "SCP/TAPS" proteins of eukaryotes--developing a framework for fundamental research and biotechnological outcomes. Biotechnol Adv 2009;27:376-88.

Cantacessi C, Mitreva M, Jex AR, Young ND, Campbell BE, Hall RS, et al. Massively parallel sequencing and analysis of the Necator americanus transcriptome. PLoS Negl Trop Dis 2010;4:e684.

Chen JQ, Galanakis D, Ganellin CR, Dunn PM, Jenkinson DH. bis-Quinolinium cyclophanes: 8,14diaza-1,7(1, 4)-diquinolinacyclotetradecaphane (UCL 1848), a highly potent and selective, nonpeptidic blocker of the apamin-sensitive $\mathrm{Ca}(2+)$-activated $\mathrm{K}(+)$ channel. J Med Chem 2000;43:3478-81.

Collaborative Computational Project Number 4. The CCP4 suite: programs for protein crystallography. Acta Crystallogr 1994;D50:760-3.

Curatolo M, Petersen-Felix S, Arendt-Nielsen L, Giani C, Zbinden AM, Radanov BP. Central hypersensitivity in chronic pain after whiplash injury. Clin J Pain 2001;17:306-15.

DeLano W. The PyMOL Molecular Graphics System. http://www.pymol.org 2002.

Diemert DJ, Bethony JM, Hotez PJ. Hookworm vaccines. Clin Infect Dis 2008;46:282-8.

Dilly S, Lamy C, Marrion NV, Liégeois J, Seutin V. Ion-channel modulators: more diversity than previously thought. Chembiochem 2011;12:1808-12.

Dolga AM, Letsche T, Gold M, Doti N, Bacher M, Chiamvimonvat N, et al. Activation of KCNN3/SK3/K(Ca)2.3 channels attenuates enhanced calcium influx and inflammatory cytokine production in activated microglia. Glia 2012;60:2050-64.

Emsley P, Cowton K. Coot: Model-Building Tools for Molecular Graphics. Acta Crystallogr 2004;D60:2126-32.

Faber ESL, Sah P. Physiological role of calcium-activated potassium currents in the rat lateral amygdala. J Neurosci 2002;22:1618-28.

Fay AJ, Qian X, Jan YN, Jan LY. SK channels mediate NADPH oxidase-independent reactive 
oxygen species production and apoptosis in granulocytes. Proc Natl Acad Sci U S A

2006;103:17548-53.

Fernández C, Szyperski T, Bruyère T, Ramage P, Mösinger E, Wüthrich K. NMR solution structure of the pathogenesis-related protein P14a. J Mol Biol 1997;266:576-93.

Ferreira I, Smyth D, Gaze S, Aziz A, Giacomin P, Ruyssers N, et al. Hookworm excretory/secretory products induce interleukin-4 (IL-4)+ IL-10+ CD4+ T cell responses and suppress pathology in a mouse model of colitis. Infect Immun 2013;81:2104-11.

Gibbs GM, Roelants K, O'Bryan MK. The CAP superfamily: cysteine-rich secretory proteins, antigen 5, and pathogenesis-related 1 proteins--roles in reproduction, cancer, and immune defense.

Endocr Rev 2008;29:865-97.

Goud GN, Bottazzi ME, Zhan B, Mendez S, Deumic V, Plieskatt J, et al. Expression of the Necator americanus hookworm larval antigen Na-ASP-2 in Pichia pastoris and purification of the recombinant protein for use in human clinical trials. Vaccine 2005;23:4754-64.

Gwak YS, Hulsebosch CE. Neuronal hyperexcitability: a substrate for central neuropathic pain after spinal cord injury. Curr Pain Headache Rep 2011;15:215-22.

Habermann E. Apamin. Pharmacol Ther 1984;25:255-70.

Hart IK, Maddison P, Newsom-Davis J, Vincent A, Mills KR. Phenotypic variants of peripheral nerve hyperexcitability. Brain 2002;125:1887-95.

Hemdan E, Zhao Y, Sulkowski E, Porath J. Surface topography of histidine residues: a facile probe by immobilized metal ion affinity chromatography. Proc Natl Acad Sci 1989;86:1811-5.

Hofmann A, Proust J, Dorowski A, Schantz R, Huber R. Annexin 24 from Capsicum annuum. Xray structure and biochemical characterization. J Biol Chem 2000a;275:8072-82.

Hofmann A, Zdanov A, Genschik P, Ruvinov S, Filipowicz W, Wlodawer A. Structure and mechanism of activity of the cyclic phosphodiesterase of Appr>p, a product of the tRNA splicing reaction. EMBO J 2000b;19:6207-17.

Hofmann A, Wlodawer A. PCSB - a program collection for structural biology and biophysical chemistry. Bioinformatics 2002;18:209-10.

Hotez PJ, Bethony JM, Diemert DJ, Pearson M, Loukas A. Developing vaccines to combat hookworm infection and intestinal schistosomiasis. Nat Rev Microbiol 2010;8:814-26.

Hougaard C, Eriksen BL, Jørgensen S, Johansen TH, Dyhring T, Madsen LS, et al. Selective positive modulation of the SK3 and SK2 subtypes of small conductance Ca2+-activated $\mathrm{K}+$ channels. Br J Pharmacol 2007;151:655-65.

Jäger H, Adelman JP, Grissmer S. SK2 encodes the apamin-sensitive $\mathrm{Ca}(2+)$-activated $\mathrm{K}(+)$ channels in the human leukemic T cell line, Jurkat. FEBS Lett 2000;469:196-202.

Jones TA, Zou JY, Cowan S, Kjeldgaard M. Improved methods for building protein models in electron density maps and location of errors in these models. Acta Crystallogr A 1991;47:110-9. Kabsch W. Automatic processing of rotation diffraction data from crystals of initially unknown symmetry and cell constants. J Appl Cryst 1993;26:795-800.

Kerrigan JE. http://www2.umdnj.edu/ kerrigje. 2003.

Köhler M, Hirschberg B, Bond CT, Kinzie JM, Marrion NV, Maylie J, et al. Small-conductance, calcium-activated potassium channels from mammalian brain. Science 1996;273:1709-14.

Koob GF, Le Moal M. Drug addiction, dysregulation of reward, and allostasis.

Neuropsychopharmacology 2001;24:97-129.

Leslie A. Recent changes to the MOSFLM package for processing film and image plate data. Joint CCP4 + ESF-EAMCB Newsletter on Protein Crystallography 1992;26.

Lim EK, Roberts MR, Bowles DJ. Biochemical characterization of tomato annexin p35 Independence of calcium binding and phosphatase activities. J. Biol. Chem. 1998;273:34920-5. Lin MT, Adelman JP, Maylie J. Modulation of endothelial SK3 channel activity by $\mathrm{Ca}^{2}+$ dependent caveolar trafficking. Am J Physiol Cell Physiol 2012;303:C318-27. 
Lobley A, Sadowski MI, Jones D. pGenTHREADER and pDomTHREADER: new methods for improved protein fold recognition and superfamily discrimination. Bioinformatics 2009;25:1761-7. Loukas A, Gaze S, Mulvenna JP, Gasser RB, Brindley PJ, Doolan DL, et al. Vaccinomics for the major blood feeding helminths of humans. OMICS 2011;15:567-77.

MacKintosh C. . In: Hardie DG, editor. Protein phosphorylation: a practical approach. IRL Press, New York, 1993. p. 221

McClung A, Carroll A, Battey N. Identification and characterisation of ATPase activity associated with maize (Zea mays) annexins. Biochem J 1994;303:709-12.

Milne T, Abbenante G, Tyndall J, Halliday J, Lewis R. Isolation and characterisation of a cone snail protease with homology to CRISP proteins of the pathogenesis-related protein superfamily. $\mathrm{J}$ Mol Biol 2003;278:31105-10.

Monaghan AS, Benton DCH, Bahia PK, Hosseini R, Shah YA, Haylett DG, et al. The SK3 subunit of small conductance Ca2+-activated $\mathrm{K}+$ channels interacts with both SK1 and SK2 subunits in a heterologous expression system. J Biol Chem 2004;279:1003-9.

Muchowski PJ, Zhang L, Chang ER, Soule HR, Plow EF, Moyle M. Functional interaction between the integrin antagonist neutrophil inhibitory factor and the I domain of CD11b/CD18. J Biol Chem 1994;269:26419-23.

Mulvenna J, Hamilton B, Nagaraj SH, Smyth D, Loukas A, Gorman JJ. Proteomics analysis of the excretory/secretory component of the blood-feeding stage of the hookworm, Ancylostoma caninum. Mol Cell Proteomics 2009;8:109-21.

Nagayama T, Fukushima Y, Hikichi H, Yoshida M, Suzuki-Kusaba M, Hisa H, et al. Interaction of $\mathrm{SK}(\mathrm{Ca})$ channels and L-type $\mathrm{Ca}(2+)$ channels in catecholamine secretion in the rat adrenal gland. Am J Physiol Regul Integr Comp Physiol 2000;279:R1731-6.

Osman A, Wang CK, Winter A, Loukas A, Tribolet L, Gasser RB, et al. Hookworm SCP/TAPS protein structure - A key to understanding host-parasite interactions and developing new interventions. Biotechnol Adv 2012;30:652-7.

Quesada I, Chin WC, Steed J, Campos-Bedolla P, Verdugo P. Mouse mast cell secretory granules can function as intracellular ionic oscillators. Biophys J 2001;80:2133-9.

Schlichter LC, Kaushal V, Moxon-Emre I, Sivagnanam V, Vincent C. The Ca2+ activated SK3 channel is expressed in microglia in the rat striatum and contributes to microglia-mediated neurotoxicity in vitro. J Neuroinflammation 2010;7:4.

Suzuki N, Yamazaki Y, Brown RL, Fujimoto Z, Morita T, Mizuno H. Structures of pseudechetoxin and pseudecin, two snake-venom cysteine-rich secretory proteins that target cyclic nucleotide-gated ion channels: implications for movement of the C-terminal cysteine-rich domain. Acta Crystallogr D 2008;64:1034-42.

Tamarina NA, Wang Y, Mariotto L, Kuznetsov A, Bond C, Adelman J, et al. Small-conductance calcium-activated $\mathrm{K}+$ channels are expressed in pancreatic islets and regulate glucose responses. Diabetes 2003;52:2000-6.

Uceda G, Artalejo AR, López MG, Abad F, Neher E, García AG. Ca(2+)-activated K+ channels modulate muscarinic secretion in cat chromaffin cells. J Physiol 1992;454:213-30.

van der Spoel D, Lindahl E, Hess B, Groenhof G, Mark AE, Berendsen HJC. GROMACS: Fast, flexible and free. J Comp Chem 2005;26:1701-18.

van Galen J, Olrichs NK, Schouten A, Serrano RL, Nolte-'t Hoen ENM, Eerland R, et al. Interaction of GAPR-1 with lipid bilayers is regulated by alternative homodimerization. Biochim Biophys Acta 2012;1818:2175-83.

Wang CK, Weeratunga SK, Pacheco CM, Hofmann A. DMAN: a Java tool for analysis of multiwell differential scanning fluorimetry experiments. Bioinformatics 2012;28:439-40.

Wang Y, Kuo J, Lee S, Liu J, Hsieh Y, Shih Y, et al. Cobra CRISP functions as an inflammatory modulator via a novel Zn2+- and heparan sulfate-dependent transcriptional regulation of endothelial 
cell adhesion molecules. J Biol Chem 2010;285:37872-83.

Wulff H, Kolski-Andreaco A, Sankaranarayanan A, Sabatier J, Shakkottai V. Modulators of smalland intermediate-conductance calcium-activated potassium channels and their therapeutic indications. Curr Med Chem 2007;14:1437-57.

Zheng L, Baumann U, Reymond J. An efficient one-step site-directed and site-saturation mutagenesis protocol. Nucleic Acids Res 2004;32:e115. 


\section{Figure Legends}

\section{Figure 1}

Three-dimensional structure of Na-ASP-2.

The cartoon (left) and surface (right) representations show the same view of the molecule. Left: The side chains of residues of the tetrad Glu99, His 88, His148 and Glu125, as well as those of cysteine residues involved in disulphide bonds are drawn explicitly. The N-terminal PR-1 domain is coloured brown, and the C-terminal Hinge domain is coloured violet. Right: Electrostatic potentials are mapped onto the surface with red indicating acidic and blue indicating basic properties. Figures prepared with PyMOL (DeLano, 2002).

\section{Figure 2}

Crystal structures of $\mathrm{Na}$-ASP-2 in complex with $\mathrm{Co}^{2+}, \mathrm{Ni}^{2+}, \mathrm{Cu}^{2+}$ and $\mathrm{Zn}^{2+}$ (from left to right).

For each metal ion, the anomalous electron density contoured at $3 \sigma$ is shown in magenta. The side chains of residues Glu99, His88, His148 and Glu125 are drawn explicitly; water molecules are rendered as red spheres. Figures prepared with PyMOL (DeLano, 2002).

\section{Figure 3}

Modelled conformations of an SK3-derived peptide to Na-ASP-2.

Comparison of binding modes of the SK3 peptide to $\mathrm{Na}$-ASP-2 as predicted by molecular dynamics simulations. Direction 1 shows the binding modes obtained with the peptide oriented $\mathrm{N} \rightarrow \mathrm{C}$ (left to right), direction 2 shows the results for the opposite direction. The top panel illustrates binding modes obtained in the absence and the middle panel in the presence of a zinc ion, coordinated to the tandem histidine motif. All binding modes shown are representative conformations taken at simulation times close to 50 ns. The SK3 peptide is rendered as a blue stick model. Electrostatic potentials are mapped onto the surface of $\mathrm{Na}$-ASP-2, with red indicating acidic and blue indicating basic properties. Figures prepared with PyMOL (DeLano, 2002).

The bottom panel shows the distance of the centres of gravities between the SK3 peptide and $\mathrm{Na}$ ASP-2 in the course of the simulations in the absence (black) and presence (red) of a coordinated zinc ion. 


\section{Tables}

\section{Table 1}

Data collection and refinement statistics

\begin{tabular}{|c|c|c|c|c|}
\hline Dataset & PRP068 & PRP072 & PRP138 & PRP0140 \\
\hline PDB accession number & 4nui & 4nuk & 4nun & 4nuo \\
\hline Protein & $\mathrm{Na}$-ASP-2: $\mathrm{Co}^{2+}$ & $\mathrm{Na}$-ASP-2: $\mathrm{Ni}^{2+}$ & $\mathrm{Na}$-ASP-2: $\mathrm{Cu}^{2+}$ & $\mathrm{Na}$-ASP-2:: $\mathrm{Zn}^{2+}$ \\
\hline Crystallisation conditions & $\begin{array}{l}\text { 30\% PEG4000, } 20 \mathrm{mM} \\
\text { MOPS (pH 7.0) }\end{array}$ & $\begin{array}{l}32 \% \text { PEG4000, 20mM } \\
\text { MOPS (pH 7.0) }\end{array}$ & $\begin{array}{l}\text { 40\% PEG4000, } 20 \mathrm{mM} \\
\text { TRIS (pH 9.0) }\end{array}$ & $\begin{array}{l}34 \% \text { PEG 4000, 20mM } \\
\text { MOPS (pH 7.0) }\end{array}$ \\
\hline Ligand binding & $\begin{array}{l}\text { soaked with } 1 \mathrm{mM} \\
\mathrm{CoCl}_{2} \text { for } 12 \mathrm{hrs}\end{array}$ & $\begin{array}{l}\text { soaked with } 1 \mathrm{mM} \\
\mathrm{NiSO}_{4} \text { for } 12 \mathrm{hrs}\end{array}$ & $\begin{array}{l}\text { soaked with } 10 \mathrm{mM} \\
\mathrm{CuSO}_{4} \text { for } 15 \mathrm{~min}\end{array}$ & $\begin{array}{l}\text { co-crystallised with } 10 \\
\mathrm{mM} \mathrm{ZnCl}_{2}\end{array}$ \\
\hline \multicolumn{5}{|l|}{ Data collection } \\
\hline X-ray source & AS MX1 & AS MX1 & AS MX1 & AS MX1 \\
\hline Detector & ADSC Quantum & ADSC Quantum & ADSC Quantum & ADSC Quantum \\
\hline Wavelength $(\AA)$ & 0.95375 & 0.95375 & 0.95375 & 0.95375 \\
\hline Space group & $\mathrm{P} 2{ }_{1}$ & $\mathrm{P} 2_{1} 2_{1} 2_{1}$ & $\mathrm{P} 2_{1}$ & $\mathrm{P} 2_{1}$ \\
\hline Cell dimensions & $\begin{array}{l}37.3 \AA \AA, 52.2 \AA, 43.5 \AA \text {, } \\
90.0^{\circ}, 93.3^{\circ}, 90.0^{\circ}\end{array}$ & $\begin{array}{l}39.9 \AA, 62.0 \AA, 77.1 \AA \text {, } \\
90.0^{\circ}, 90.0^{\circ}, 90.0^{\circ}\end{array}$ & $\begin{array}{l}37.0 \AA, 51.3 \AA, 43.3 \AA \text {, } \\
90.0^{\circ}, 94.0^{\circ}, 90.0^{\circ}\end{array}$ & $\begin{array}{l}37.1 \AA, 51.5 \AA, 43.1 \AA, \\
90.0^{\circ}, 93.4^{\circ}, 90.0^{\circ}\end{array}$ \\
\hline Max. resolution $(\AA)$ & 1.7 & 2.4 & 2.2 & 1.8 \\
\hline Wilson B-factor $\left(\AA^{2}\right)$ & 12.4 & 38.6 & 24.5 & 13.7 \\
\hline No of unique reflections & 18426 (2669) & 7893 (1103) & 8309 (1207) & $16181(2142)$ \\
\hline Multiplicity & $7.4(7.5)$ & $12.3(12.5)$ & $7.5(7.6)$ & $7.3(5.6)$ \\
\hline Completeness & $0.996(0.992)$ & $1.00(1.00)$ & $1.00(1.00)$ & $0.985(0.900)$ \\
\hline $\mathrm{R}_{\text {sym }}{ }^{\mathrm{a}}$ & $0.046(0.142)$ & $0.114(0.476)$ & $0.054(0.219)$ & $0.051(0.201)$ \\
\hline \multicolumn{5}{|l|}{ Refinement } \\
\hline $\begin{array}{l}\text { No of reflections in working / test } \\
\text { set }\end{array}$ & 17032 / 918 & 6838 / 330 & 7641 / 369 & 14856 / 798 \\
\hline No of non-H protein atoms & 1444 & 1444 & 1444 & 1444 \\
\hline
\end{tabular}




\begin{tabular}{|c|c|c|c|c|}
\hline Visible residues & $18-210$ & $18-210$ & $18-210$ & $18-210$ \\
\hline No of water molecules & 313 & 81 & 76 & 198 \\
\hline No of ions & $1 \mathrm{Co}^{2+}$ & $1 \mathrm{Ni}^{2+}$ & $1 \mathrm{Cu}^{2+}$ & $1 \mathrm{Zn}^{2+}$ \\
\hline $\begin{array}{l}\text { Average B-factor }\left(\AA^{2}\right) \\
\text { Protein } \\
\text { Solvent } \\
\text { Ions }\end{array}$ & $\begin{array}{l}10.1 \\
21.1 \\
25.9\end{array}$ & $\begin{array}{l}26.9 \\
27.6 \\
38.6\end{array}$ & $\begin{array}{l}19.4 \\
23.2 \\
40.7\end{array}$ & $\begin{array}{l}14.0 \\
23.1 \\
17.5\end{array}$ \\
\hline rmsd B-factor for bonded atoms $\left(\AA^{2}\right)$ & 2.59 & 3.99 & 3.77 & 2.23 \\
\hline rmsd bond lengths ( $\AA$ ) & 0.006 & 0.008 & 0.009 & 0.007 \\
\hline rmsd bond angles $\left({ }^{\circ}\right)$ & 0.971 & 1.136 & 1.264 & 1.188 \\
\hline $\begin{array}{l}\text { MolProbity analysis } \\
\text { Ramachandran outliers (\%) } \\
\text { Ramachandran favoured (\%) } \\
\text { Rotamer outliers (\%) } \\
\text { C-beta outliers } \\
\text { Clashscore } \\
\text { Overall score }\end{array}$ & $\begin{array}{l}0.5 \\
97.9 \\
1.3 \\
1 \\
6.06 \\
1.45\end{array}$ & $\begin{array}{l}1.0 \\
94.8 \\
4.6 \\
1 \\
13.4 \\
2.5\end{array}$ & $\begin{array}{l}1.0 \\
96.3 \\
1.3 \\
1 \\
4.47 \\
1.56\end{array}$ & $\begin{array}{l}0.5 \\
98.4 \\
3.3 \\
0 \\
6.47 \\
1.75\end{array}$ \\
\hline R-factor ${ }^{c}$ & $0.156(0.178)$ & $0.183(0.223)$ & $0.175(0.236)$ & $0.164(0.200)$ \\
\hline $\mathrm{R}_{\text {free }}$ factor $^{\mathrm{d}}$ & $0.191(0.188)$ & $0.244(0.265)$ & $0.231(0.293)$ & $0.189(0.262)$ \\
\hline
\end{tabular}

Values in parentheses refer to the last resolution shell.

${ }^{\mathrm{a}} \mathrm{R}_{\text {sym }}=\Sigma|\mathrm{I}-<\mathrm{I}>| / \Sigma \mathrm{I}$, where I is the observed intensity, and $<\mathrm{I}>$ is the average intensity obtained from multiple observations of symmetry-related reflections after rejections.

${ }^{b}$ MolProbity analysis as implemented in PHENIX (Adams et al., 2010).

${ }^{\mathrm{c}} \mathrm{R}$-factor $=\Sigma|| \mathrm{F}_{\mathrm{o}}|-| \mathrm{F}_{\mathrm{c}}|| / \Sigma\left|\mathrm{F}_{\mathrm{o}}\right|$, where $\mathrm{F}_{\mathrm{o}}$ and $\mathrm{F}_{\mathrm{c}}$ are the observed and calculated structure factors, respectively.

${ }^{\mathrm{d}} \mathrm{R}_{\text {free }}$ defined in (Brünger, 1992). 
Table 2

Dodecapeptides from the phage display-12 peptide library that bound to immobilised Na-ASP-2

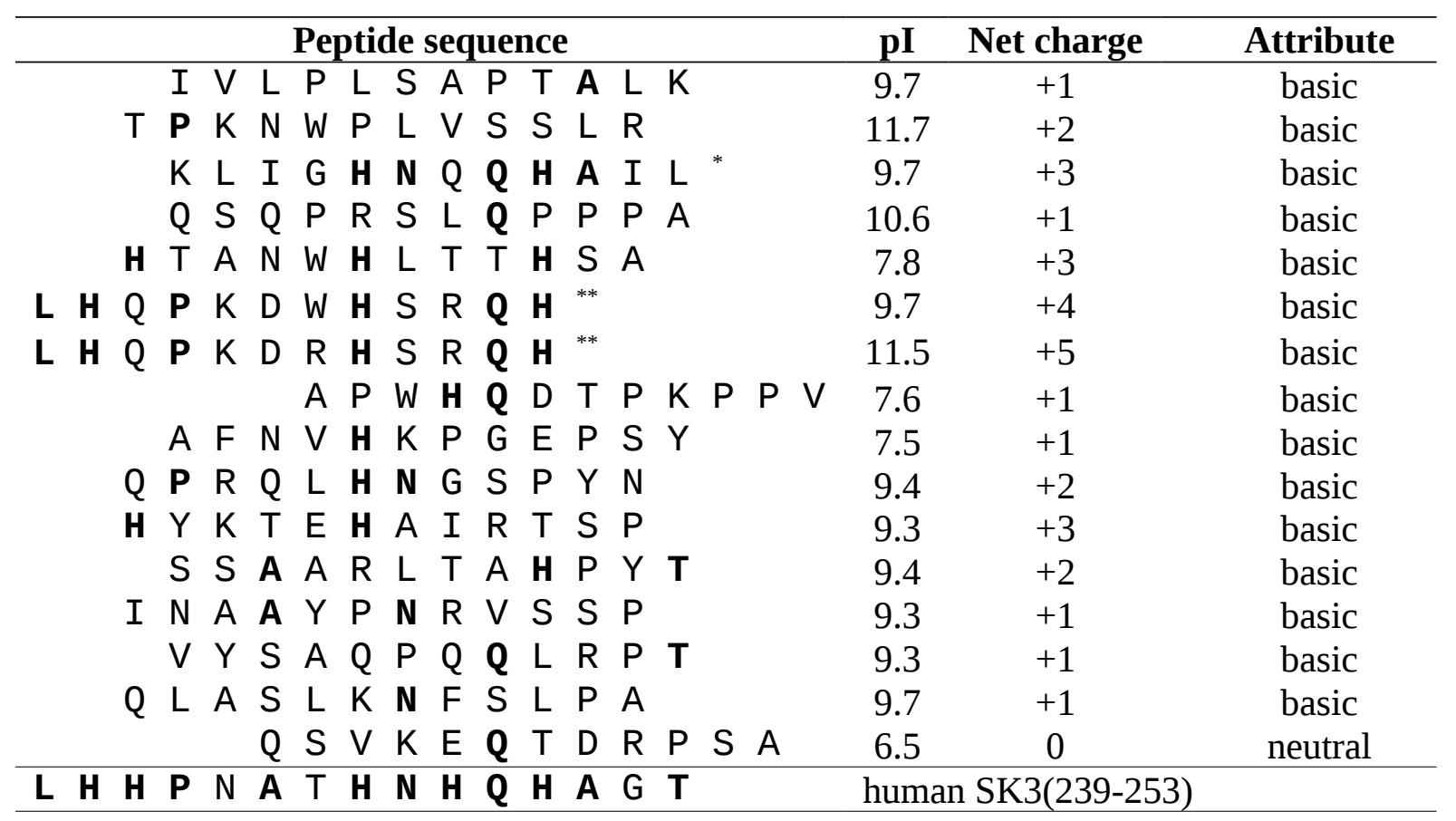

${ }^{*}$ Peptide identified twice in two independent screens.

${ }^{* *}$ These peptides differ by a single residue (Trp7 for Arg7). 
Table 3

Ligand binding results

\begin{tabular}{|c|c|c|}
\hline Ligand & $\begin{array}{l}\text { Interactions observed } \\
\text { in crystal structure }\end{array}$ & $\begin{array}{l}\text { Differential scanning fluorimetry } \\
\qquad \Delta \mathrm{T}_{1 / 2}(\mathrm{~K})^{\mathrm{b}}\end{array}$ \\
\hline $\mathrm{Mn}^{2+}$ & not bound & $-0.23(0.0 ; 3)$ \\
\hline $\mathrm{Co}^{2+}$ & $\begin{array}{ll}\text { His 88-NE2 } & (2.3) \\
\mathrm{His} & 148-\mathrm{NE} 2(2.6) \\
\mathrm{H}_{2} \mathrm{O} 60-\mathrm{O} & (2.3) \\
\mathrm{H}_{2} \mathrm{O} 91-\mathrm{O} & (2.5) \\
\mathrm{H}_{2} \mathrm{O} 172-\mathrm{O} & (2.8) \\
\mathrm{H}_{2} \mathrm{O} 194-\mathrm{O} & (2.4)\end{array}$ & $+0.03(0.15 ; 3)$ \\
\hline $\mathrm{Ni}^{2+}$ & $\begin{array}{l}\text { His 88-NE2 (2.3) } \\
\mathrm{His} 148-\mathrm{NE} 2(2.5) \\
\mathrm{H}_{2} \mathrm{O} 59-\mathrm{O} \\
\mathrm{H}_{2} \mathrm{O} \text { 74-O }\end{array}$ & $-0.42(0.0 ; 3)$ \\
\hline $\mathrm{Cu}^{2+}$ & $\begin{array}{l}\text { His 88-NE2 (2.3) } \\
\text { His 148-NE2(2.5) } \\
\mathrm{H}_{2} \mathrm{O} 32-\mathrm{O}\end{array}$ & $+6.0(0.06 ; 3)$ \\
\hline $\mathrm{Zn}^{2+}$ & $\begin{array}{lr}\text { His 88-NE2 } & (2.2) \\
\mathrm{His} & 148-\mathrm{NE} 2(2.3) \\
\mathrm{H}_{2} \mathrm{O} 24-\mathrm{O} & (2.5) \\
\mathrm{H}_{2} \mathrm{O} 74-\mathrm{O} & (2.7) \\
\mathrm{H}_{2} \mathrm{O} \text { 77-O } & (2.5)\end{array}$ & $+1.1(0.13 ; 3)$ \\
\hline SK3 peptide & not bound & $+1.1(0.15 ; 6)$ \\
\hline SK3 peptide, $\mathrm{Mn}^{2+}$ & not bound & $+1.0(0.13 ; 3)$ \\
\hline SK3 peptide, $\mathrm{Co}^{2+}$ & not bound & $+1.0(0.13 ; 3)$ \\
\hline SK3 peptide, $\mathrm{Ni}^{2+}$ & not bound & $+1.3(0.05 ; 3)$ \\
\hline SK3 peptide, $\mathrm{Cu}^{2+}$ & not bound & $+1.4(0.12 ; 3)$ \\
\hline
\end{tabular}


${ }^{a}$ Distances are given in $\AA$.

${ }^{\mathrm{b}} \Delta \mathrm{T}_{1 / 2}$ is defined as the difference between $\mathrm{T}_{1 / 2}$ (protein:ligand) and $\mathrm{T}_{1 / 2}$ (protein: $\left.\mathrm{H}_{2} \mathrm{O}\right)$. Values given are the average of $N$ repeats, with the standard deviation and $N$ given in brackets. The effect of water addition to protein caused a temperature shift of $\Delta \mathrm{T}_{1 / 2}=\mathrm{T}_{1 / 2}\left(\right.$ protein: $\left.\mathrm{H}_{2} \mathrm{O}\right)-\mathrm{T}_{1 / 2}($ protein $)=0.13 \mathrm{~K}$ $(0.0 ; 3)$. 


\section{Table 4}

Na-ASP-2:SK3 binding modes after molecular dynamics simulations

\begin{tabular}{|c|c|c|c|c|c|}
\hline Protein & Peptide & Direction & $\begin{array}{c}E^{\mathrm{a}} \\
\text { in } \mathrm{kJ} \mathrm{mol}^{-1}\end{array}$ & $\begin{array}{l}\text { No of hydrogen bonds } \\
\text { (Na-ASP-2 - SK3) }\end{array}$ & $\begin{array}{c}\text { Distance }^{\mathrm{b}, \mathrm{c}} \\
\text { Na-ASP-2 - SK3 }\end{array}$ \\
\hline$N a$-ASP-2 & SK3 & 1 & -335283 & 12 & $12.6 \AA(0.3 \AA)$ \\
\hline Na-ASP-2 & SK3 & 2 & -332221 & 6 & $16.0 \AA(0.8 \AA)$ \\
\hline$N a$-ASP-2: $\mathrm{Zn}^{2+}$ & SK3 & 1 & -337809 & 9 & $14.7 \AA(0.5 \AA)$ \\
\hline $\mathrm{Na}$-ASP-2: $\mathrm{Zn}^{2+}$ & SK3 & 2 & -334678 & 3 & $17.5 \AA(0.6 \AA \AA)$ \\
\hline
\end{tabular}

${ }^{\text {a}}$ Total energy (average over 50 ns simulation time).

${ }^{\mathrm{b}}$ The values given show the average and the standard deviation in the period 15 - $50 \mathrm{~ns}$.

${ }^{\mathrm{c}}$ Measured as distance of the centres of gravity. 


\section{Table 5}

Phosphohydrolase activity of wild-type and mutant $\mathrm{Na}$-ASP-2

\begin{tabular}{lcccc}
\hline Additive & Control & Na-ASP-2 & Na-ASP-2-H88A & Na-ASP-2:SK3 \\
\hline EDTA & -2.5 & 27 & 1.2 & 5.4 \\
$\mathrm{Mg}^{2+}$ & -0.54 & 3.1 & -1.5 & 4.8 \\
$\mathrm{Ca}^{2+}$ & 0.4 & 15 & 18 & 4.6 \\
$\mathrm{Mn}^{2+}$ & 1.6 & 9.6 & 2.1 & 4.3 \\
$\mathrm{Co}^{2+}$ & -2.9 & 23 & 0.9 & 5.6 \\
$\mathrm{Ni}^{2+}$ & -1.8 & 12 & 1.3 & -0.4 \\
$\mathrm{Cu}^{2+}$ & -3.7 & 15 & -3.7 & 3.8 \\
$\mathrm{Zn}^{2+}$ & 1.3 & 13 & -1.9 & 4.3 \\
\hline
\end{tabular}

Values given are specific activity in units per mg as determined by a stopped flow assay at $\mathrm{pH} 7.0$ with $p$-nitrophenyl phosphate as substrate and $5 \mu \mathrm{M}$ enzyme. Additives were added at a final concentration of $5 \mu \mathrm{M}$; the SK3 peptide was added at a final concentration of $50 \mu \mathrm{M}$. 


\section{Figures}

\section{Figure 1}
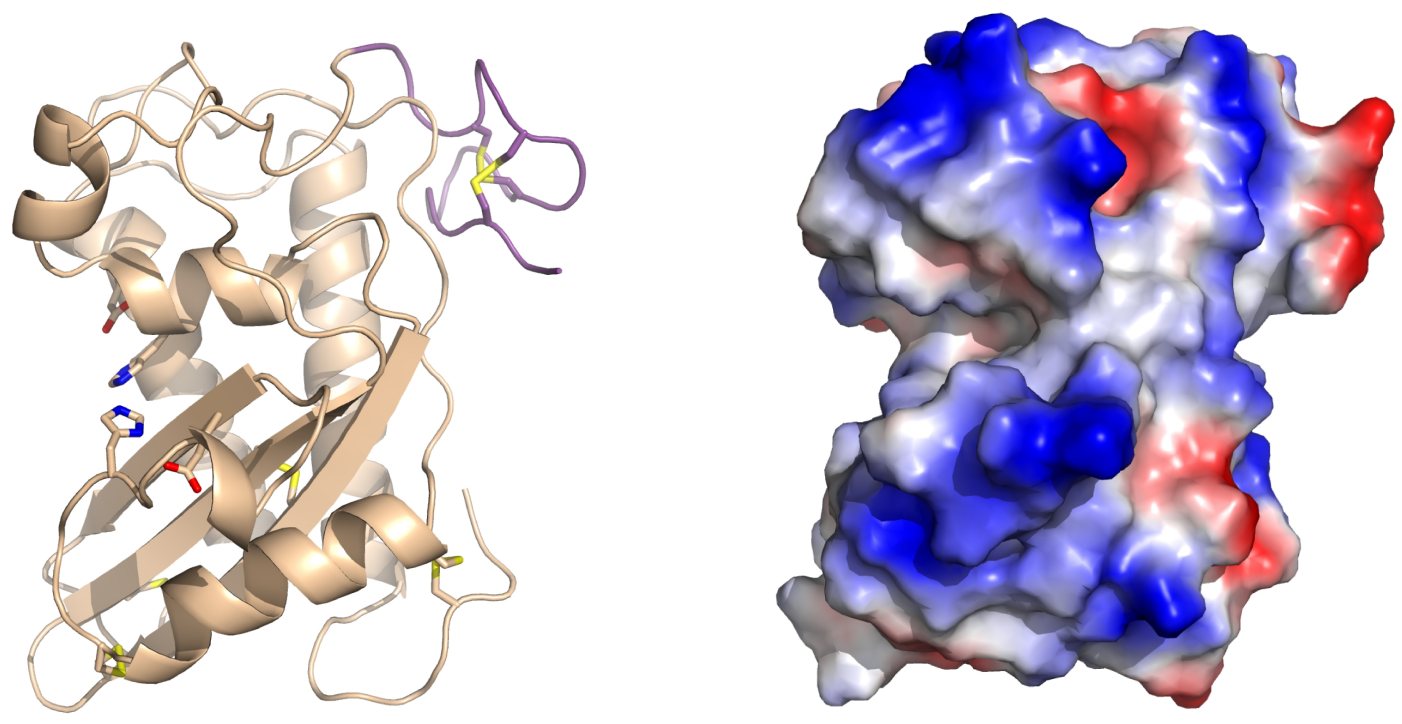

Three-dimensional structure of Na-ASP-2. The cartoon (left) and surface (right) representations show the same view of the molecule. Left: The side chains of residues of the tetrad Glu99, His 88, His148 and Glu125, as well as those of cysteine residues involved in disulphide bonds are drawn explicitly. The N-terminal PR-1 domain is coloured brown, and the C-terminal Hinge domain is coloured violet. Right: Electrostatic potentials are mapped onto the surface with red indicating acidic and blue indicating basic properties. Figures prepared with PyMOL [4789].

\section{Figure 2}
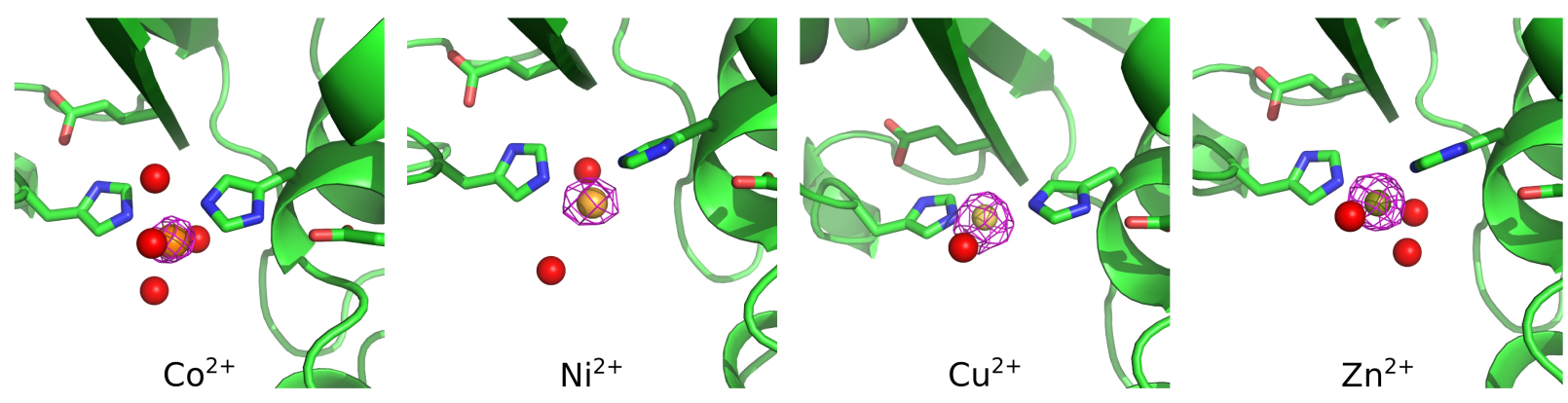

Crystal structures of $\mathrm{Na}$-ASP-2 in complex with $\mathrm{Co}^{2+}, \mathrm{Ni}^{2+}, \mathrm{Cu}^{2+}$ and $\mathrm{Zn}^{2+}$ (from left to right). For each metal ion, the anomalous electron density contoured at $3 \sigma$ is shown in magenta. The side chains of residues Glu99, His88, His148 and Glu125 are drawn explicitly; water molecules are rendered as red spheres. Figures prepared with PyMOL [4789]. 


\section{Figure 3}

Direction 1
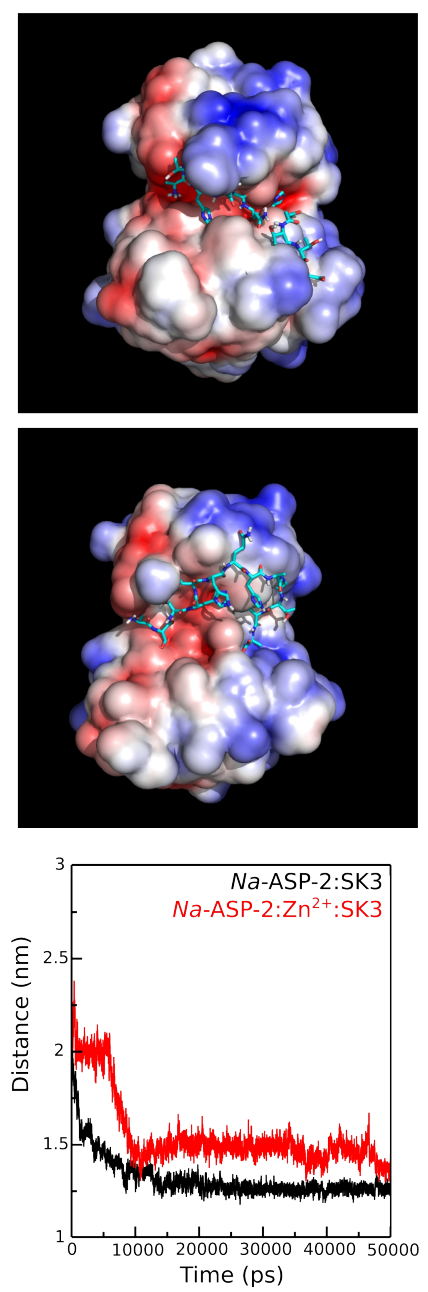

Direction 2
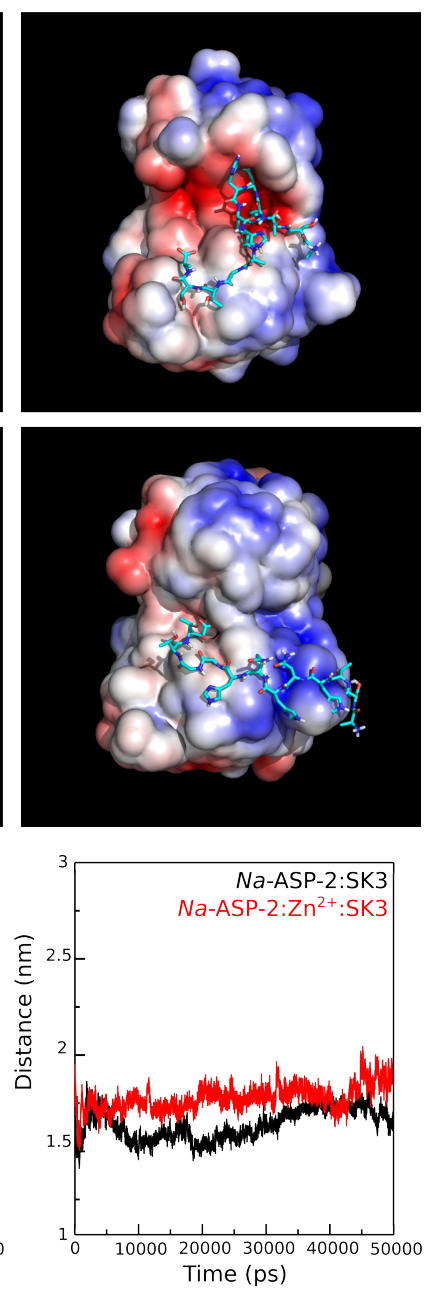

Distance between Na-ASP-2 and SK3 peptide

Comparison of binding modes of the SK3 peptide to $\mathrm{Na}$-ASP-2 as predicted by molecular dynamics simulations. Direction 1 shows the binding modes obtained with the peptide oriented $\mathrm{N} \rightarrow \mathrm{C}$ (left to right), direction 2 shows the results for the opposite direction. The top panel illustrates binding modes obtained in the absence and the middle panel in the presence of a zinc ion, coordinated to the tandem histidine motif. All binding modes shown are representative conformations taken at simulation times close to $50 \mathrm{~ns}$. The SK3 peptide is rendered as a blue stick model. Electrostatic potentials are mapped onto the surface of $\mathrm{Na}$-ASP-2, with red indicating acidic and blue indicating basic properties. Figures prepared with PyMOL [4789].

The bottom panel shows the distance of the centres of gravities between the SK3 peptide and $\mathrm{Na}$ ASP-2 in the course of the simulations in the absence (black) and presence (red) of a coordinated zinc ion. 


\section{Supplementary Data}

\section{Probing the equatorial groove of the hookworm protein and vaccine candidate antigen, $\mathrm{Na}$-ASP-2}

Lyndel Mason ${ }^{1, \dagger}$, Leon Tribolet ${ }^{2, \dagger}$, Anne Simon ${ }^{3}$, Natascha von Gnielinski ${ }^{1}$, Lisa Nienaber ${ }^{1}$, Paul Taylor $^{4}$, Charlene Willis ${ }^{1,5}$, Malcolm K Jones ${ }^{5,6}$, Paul W Sternberg ${ }^{7}$, Robin B Gasser ${ }^{8}$, Alex Loukas ${ }^{2, *}$ \& Andreas Hofmann ${ }^{1,8, *}$

\section{Figure S1}

Quality control of purified recombinant proteins.

Denaturing-reducing SDS-PAGE (12\%) using single gels (Ahn et al., 2001) of fractions obtained in the final chromatographic separation (Q-Sepharose, $0 \rightarrow 1 \mathrm{M} \mathrm{NaCl}, 20 \mathrm{mM}$ TRIS, pH 8.0) for $\mathrm{Na}$ ASP-2 and Na-ASP-2-H88A. The gels were stained with Coomassie following standard procedures. The gels show no signs of contaminating proteins.
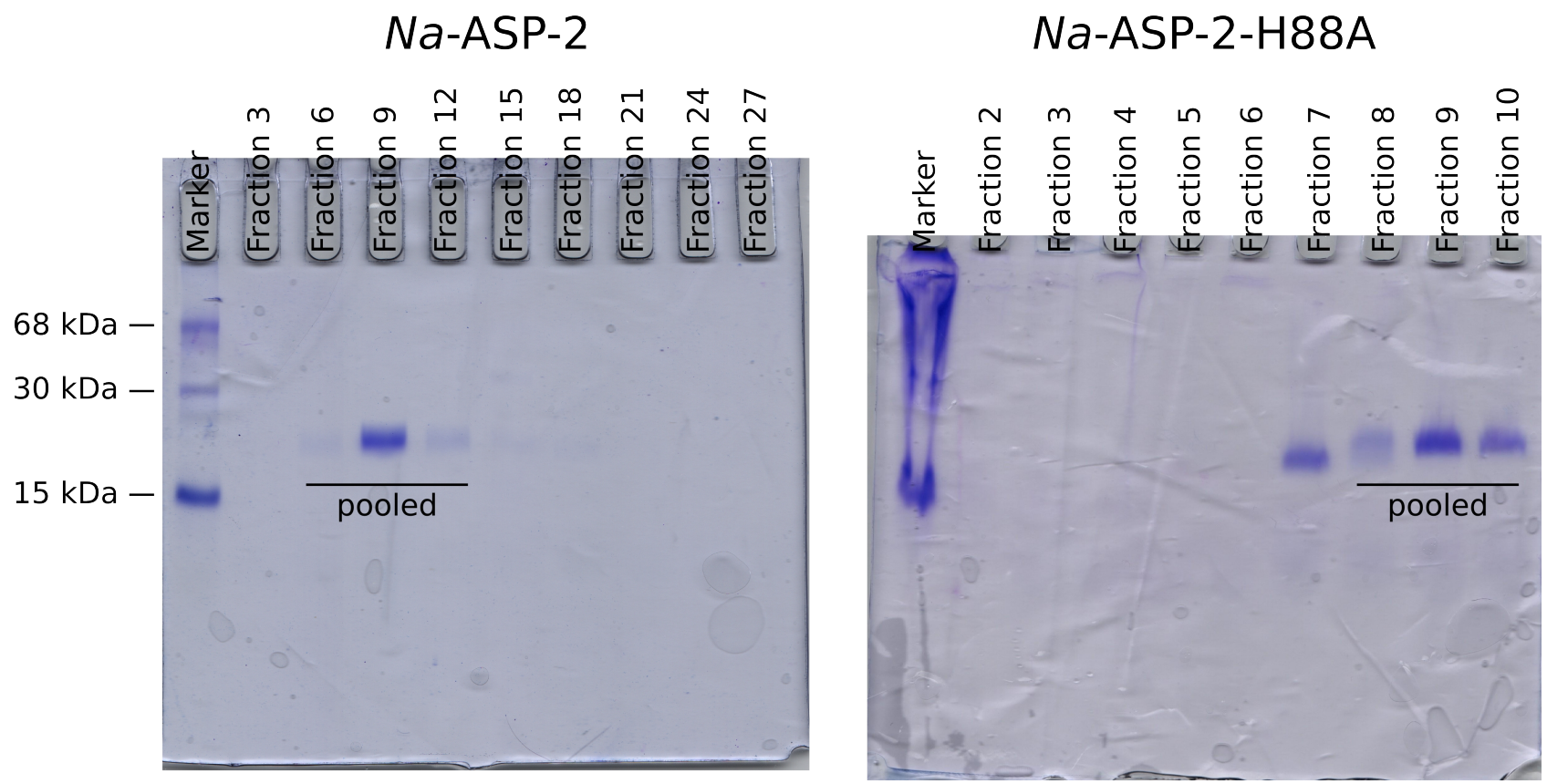

\section{References}

Ahn T, Yim S, Choi H, Yun C. Polyacrylamide gel electrophoresis without a stacking gel: use of amino acids as electrolytes. Anal. Biochem 2001;291:300-3. 